\title{
Marronage is Resistance Against the Colonizer's Construction of History
}

\begin{abstract}
The contribution is an intervention into the book Kolonierne i Vestindien [The Colonies in the West Indies] (1980) by Danish historian Ove Hornby. Pointing to the limitations and biases of Hornby's account of the St. Croix Fireburn labor revolt of 1878, the contribution is an implicit critique of the way archival sources have been put to use within the discipline of history writing in attempts to delegitimise anti-colonial resistance. It is with some ambivalence that we have chosen to also include an English translation of the Hornby text as well as our annotations, and thereby reproduce the very language we are critiquing. However, these translations have been important in order to ensure greater accessibility to a USVI readership.
\end{abstract}

Keywords: resistance, Fireburn, history-writing, colonial bias, Black redaction and annotation

»All these words from the seller, but not one word from the sold. The Kings and Captains whose words moved ships. But not one word from the cargo.«

- Zora Neale Hurston

When accessing the past, we are often forced to make do with the colonizer's archival sources and history books while the task of locating the voices of enslaved Africans and their descendants in the colonial archives is an inordinate challenge. About the approximately 13 million enslaved people who were transported on the Middle Passage between 1450 and 1900, the archives tell us almost nothing. Their history is subsumed in the innumerable financial accounts, ledgers and protocols made by slave traders, merchants or plantation owners.

The silencing continues throughout history. What follows is an excerpt from a Danish history book that discusses the 1878 Fireburn labor revolt on St. Croix. ${ }^{i}$ The past is seen exclusively through the colonizer's white gaze. Through acts of redaction and annotation, we have exposed the colonial bias inherent in this account that attempts to pass itself off as neutral.

Black feminist scholar Christina Sharpe notes that what she calls Black redaction and annotation can function as "a counter to the force of the state" - a way of returning to violent documents with the intention of seeing and reading otherwise. For Sharpe, Black redaction and annotation are tools with which to expose "the failure of words and concepts to hold in and on Black flesh" in order to "disrupt the dysgraphia that wrote a version of events that was riven with antiblackness". ii Similarly, in our case, we use these tactics as a mode of editorial revision and resistance. By striking through colonial and demeaning language, by adding the names of people involved in the Fireburn, by marking out the euphemisms used to justify Danish colonial rule, by pencilling in some of the nuances that have been lost, we are taking history writing to task. Marronage is resistance against the colonizer's construction of history. ${ }^{\text {iii }}$

i Ove Hornby. 1980. Kolonierne $i$ Vestindien. Copenhagen: Politikens Forlag.

ii Christina Sharpe. 2016. In the Wake. Durham, NC: Duke University Press, 2016, 113-130.

iii You can read Marronage's take on writing about the Fireburn on St. Croix and the Fireburn Queens in Marronage \#1. 
pagne satte sig ud over arbeidsreglementets lønbestemmelse og betalte sine sæsonarbejdere to til tre gange mere normalt kunne opnås på plantagerne. Sankt Croix blev a ligne ved en krudttønde - der behøvedes blot en gnist for at få øen til at eksplodere.

\section{3}

$$
\begin{aligned}
& \text { Bygreer po politimostenem i Frederiksteds } \\
& \text { berething "R. Petersen" }
\end{aligned}
$$

है. 5 : Sankt Croix i flammer FIREBURN

På skiftedagen den 1. oktober søgte tandnegrene-på Sankt Croix i stort tal ind til byerne - for at søge en ny plads, finde skibslejlighed bort fra øen eller blot for at få sig en glad dag.

范 Således også i 1878: I Frederiksted, der havde det store

sukkerdistrikt som opland, var der livlig omsætning i rombo-

3 derne, og stemningen blandt landarbejderne blev hurtigt oprømt og aggressiv. Hen på eftermiddagen begyndte der at 3. spredes rygter om negre, der var blevet stoppet på vej væk fra

₹en, og rundt omkring diskuteredes lønforholdene i højlydte toner. Der var uro i luften, da politiet) samlede en "stærk beruset"landarbejder op og bragte ham på hospitalet, ford ‡\% han havde skåret sin fod. pa betjentene søgte at splitte mængden, blev de mødt mød stenkast og måtte trække sig 作 Felicia Janes

Situationen var på vippen, og nogle kendte og alment ₹ respekterede hvide borgere søgte at få kegrentil at forlade byen. På dette kritiske tidspunkt kom en kvinde arlade råbte, at den kvinde løbende og råbte, at den (reger der var blevet bragt på hospitalet, nu var død som følge af politiets mishandling. Følelserne kom i kog, og det nyttede ikke, at man hurtigt kunne "konstater", meget omtalte landarbejder sov rusen fredeligt ud i sin hospitalsseng. Nu ville negrene have » retfærdighed «, og de samledes i en "truende"skare på pladsen foran fortet.

Stenene fløj gennem luften, og skønt de få soldater affyrede varselsskud, blev yderporten revet op, og besætningen måtte skyndsomt søge tilflugt i den indre fortgård. Da bombardementet med forhåndenværende kasteskyts fortsatte, og den sidste port begyndte at give efter, gik de indespærrede over til Hedt ned ic prost ex det clint at syuscintian er hol de hrich ravip

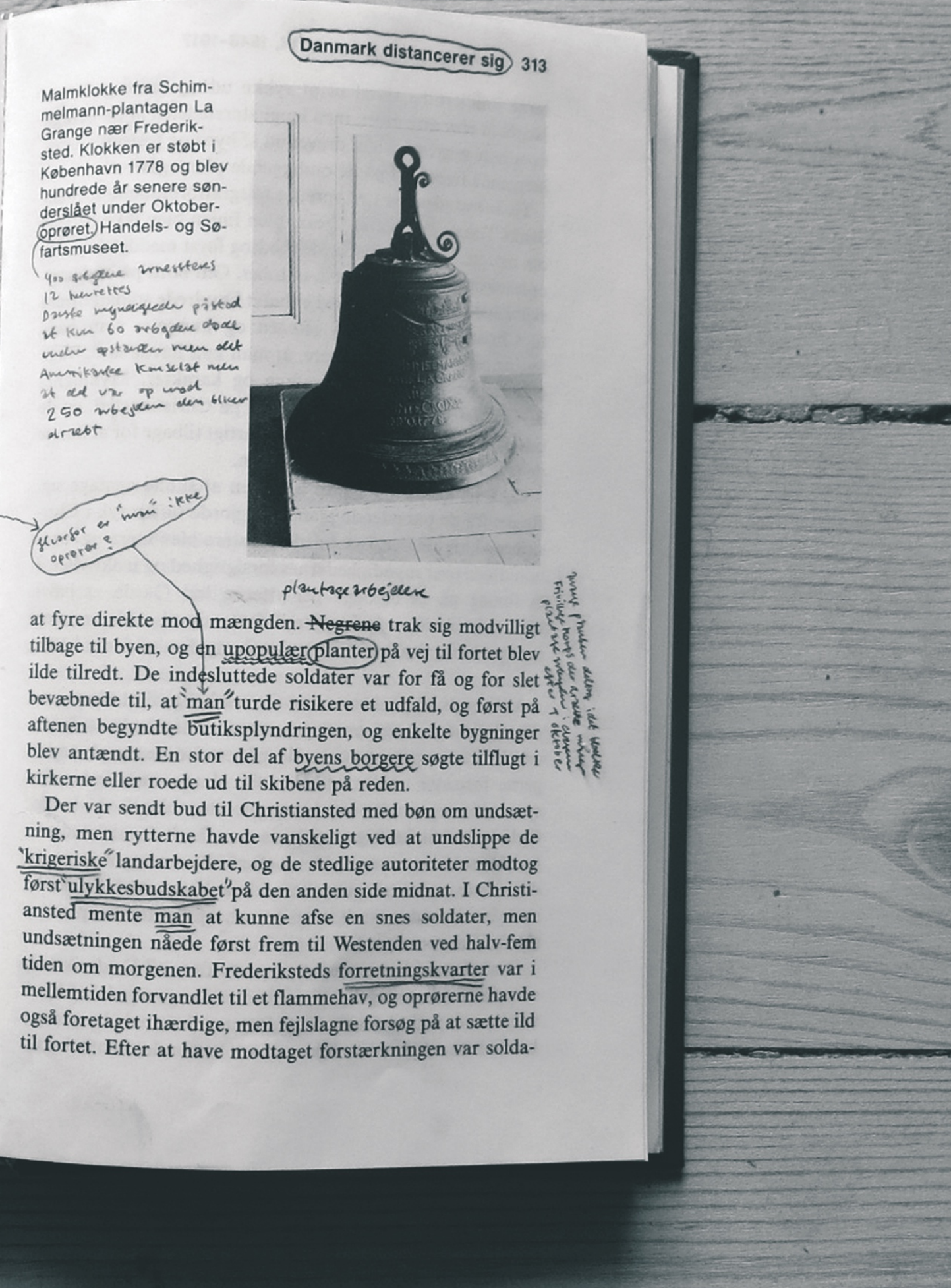




\section{Dismantling under Representative Government, 1848-1917}

paign disregarded the wage regulations in the Labor Act and paid his seasonal workers two to three times more than what could normally be earned on the plantations. Sct. Croix began to resemble a powder kega spark was all it would take to make the island explode.

\section{Sct. Croix in Flames}

Every year on transfer day, October 1st, Sct. Croix's country negroes would travel to the towns in large numbers - in order to find a new position, seeking opportunities to leave the Island by sea or simply to have a cheerful day. Such was also the case in 1878: In Frederiksted, where the big sugarcane district was located, the rum shops were bustling and the mood among the workers quickly turned excited and aggressive. During the afternoon, rumors began to spread about negroes who had been detained while trying to leave the Island, and wide and about wage conditions were discussed vociferously. There was unrest in the air as the police picked up a heavily drunken field worker and brought him to the hospital because he had cut his foot. When the police tried to dissolve the crowd, they were met with stone-throwing and were compelled to withdraw to the fort.

The situation was poised to escalate, and well-known and widely respected white citizens tried to convince the negroes to leave town. At this critical moment, a woman ran into the crowd shouting that the negro who had been brought to the hospital was now dead as a result of his mistreatment by the police. Tensions had reached a boiling point, and it was to no avail that one could quickly determine that the much-talkedabout field worker was peacefully sleeping off his intoxication in his hospital bed. Now the negroes wanted "justice", and they gathered in a threatening mob in the square in front of the fort.

Stones were flying through the air and although the few soldiers present fired warning shots, the outer gate was torn open and the soldiery had to hurriedly seek refuge in the fort's inner courtyard. When the bombardment with whatever missiles were at the crowd's disposal continued and the last gate started to give in, the trapped began to

\section{Denmark distances itself}

(Caption:) Bronze bell from the Schimmelmann plantation La Grange near Frederiksted. The bell was cast in Copenhagen in 1778 and a hundred years later it was smashed to pieces under the October rebellion. Maritime Museum of Denmark.

shoot directly at the crowd. The negroes reluctantly withdrew to the town and a widely disliked planter was badly hurt on his way to the fort. The trapped soldiers were too few in numbers and too poorly armed for one to dare to risk a fall out, and in the early evening the ransacking of stores began and a few buildings were set on fire. A large part of the town's citizens sought refuge in the churches or rowed out to the ships at the roadstead. A plea for reinforcement was sent to Christiansted, but the dispatch riders had some difficulty escaping the belligerent field workers, and the local authorities did not receive the tragic news until past midnight. In Christiansted, one decided that a few soldiers could be spared, but reinforcements did not arrive at the West End before 4.30 in the morning. In the meantime, Frederiksted's business district had been transformed into a sea of flames and the rebels had made persistent yet unsuccessful attempts to set fire to the fort. After receiving reinforcement, the soldiers were....

Excerpt from Ove Hornby. 1980. Kolonierne $i$ Vestindien. Copenhagen: Politikens Forlag, pp. 312-313.

Translation by Marronage 


\section{ANNOTATIONS AND REDACTED WORDS AND PHRASES \\ TRANSLATED IN ORDER OF APPEARANCE}

salg: sale

ophoevelse af slaveri: abolition of slavery

Arbejdsreglementet: the Labor Act

Foellessukkerkogeriet: the Central Sugar Factory

to til tre gange mere: two to three times more

Bygger på politimesteren i Frederikssteds beretning "R. Petersen": Based on the chief police officer in Frederiksted's account "R. Petersen"

Slaveriet "ophørte" i 1848 men arbejderne var bundet til plantagerne gennem et midlertidigt arbejdsreglement. Kun en dag om året kunne man ophoeve sin kontrakt.: Slavery was "abolished" in 1848 but the workers were tied to plantations through a temporary labour regulation. Only one day a year were you allowed to terminate your contract.

skiftedagen: Transfer Day

Udrejsevisum blev typisk udstedt i dagene omkring d.1.oktober: Travel visas were typically issued in the days around October 1st

rygter: rumors

Plantagearbejdere: plantation workers

negre: negroes

politiet: the police

Storkt beruset: heavily drunken

landarbejder: field worker

Henry Trotman fra plantagen Mt. Pleasant \& Plessen: Henry Trotman from the plantations Mt. Pleasant \& Plessen

Felicia James: Felicia James

kvinde: woman

neger: negro

man: one

konstatere: determine 
sov rusen fredeligt $u d$ : peacefully sleeping off his intoxication

retfaerdighed: justice

truende: threatening

Stenene fløj gennem luften (...) de inspcerrede gik over til..:

Stones were flying through the air (...) the trapped began to...

Helt ned $i$ sproget er det klart at synsvinklen er hos de hvide, selvom de "sorte" arbejdere pga. arbejdsreglementet drives til kamp: Right down to the level of language it is clear that the point of view is that of the whites, even though the "black" workers are driven to action because of the Labor Act

Danmark distancerer sig: Danmark distances itself

oprøret: the rebellion

400 arbejdere arresteres, 12 henrettes. Danske myndigheder påstod at kun 60 arbejdere døde under opstanden, men det Amerikanske konsulat mener det var op mod 250 arbejdere der blev drcebt.: 400 workers are arrested. 12 executed. The Danish authorities claimed that only 60 workers died during the uprising, but the American Consulate are convinced it was more than 250 workers who were killed.

Hvorfor er "man" ikke oprører?: How come "one" is not a rebel?

Mange plantere deltog $i$ det frivilligkorps der drcebte mange plantagearbejdere $i$ dagene efter den 1. oktober: Many planters participated in the volunteer militia that murdered many plantation workers in the days following October 1st

upopulcer: disliked

man: one

byens borgere: The town's citizens

krigeriske: belligerent

ulykkesbudskabet: tragic news

forretningskvarter: business district 
Marronage is a Copenhagen-based decolonial feminist collective that emerged in 2016 to politicise the centennial of the sale of the former Danish West Indies to the United States. Together with other likeminded collectives and comrades, we organise discursive events, workshops, demonstrations, actions, interventions, texts, video, audio, imagery, financial support with the aim of working towards the abolition of a still colonizing world. Marronage, redaktion@marronage.dk. 